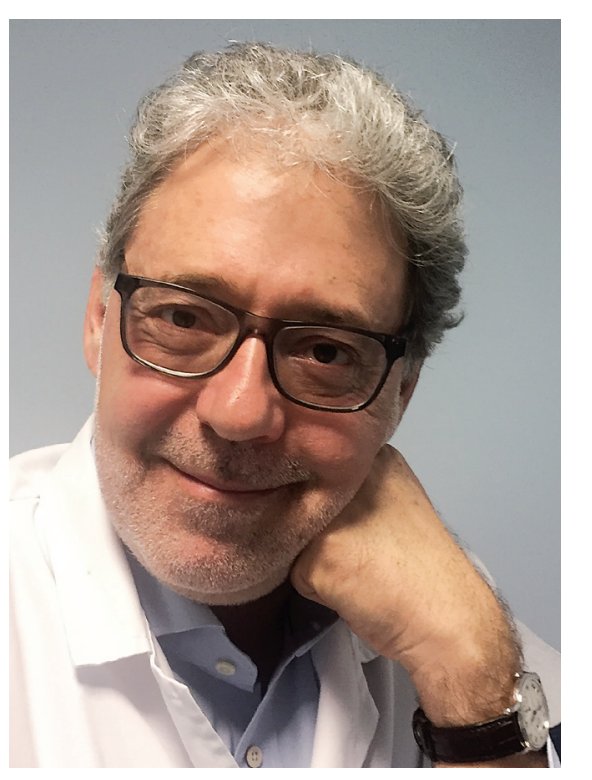

\title{
O INTERNATO MÉDICO NOS HOSPITAIS CUF
}

João Paulo Farias

Em mais uma edição da Gazeta Médica, gostaria de começar este editorial por realçar a qualidade dos artigos que nesta e nas anteriores edições temos testemunhado, seja em artigos de revisão, de investigação ou apresentação de casos clínicos.

Desafio todos a pensarem na Gazeta Médica para as vossas publicações. Só assim poderemos desenvolvê-la e aumentar a sua relevância no panorama das revistas médicas generalistas em Portugal.

Hoje gostaria de vos falar sobre um tema que me é muito caro: o Internato Médico. Especificamente o Internato Médico nos nossos hospitais CUF.

O Internato Médico enfrenta vários desafios atualmente em Portugal:

- Candidatos ao Internato Médico em número claramente superior ao das capacidades formativas que o país tem anualmente (em 2017 cerca de 2400 candidatos para 1750 vagas disponíveis), situação que só se vai agravar no futuro próximo;

- Falta de formadores (orientadores de formação), devido ao crescente número de médicos a sair das instituições públicas em algumas especialidades e ao número de médicos especialistas na faixa etária dos 40 anos (os formadores por excelência) ser baixo resultante da redução franca do numerus clausus das Faculdades de Medicina na década de 1990;

- Questões relacionadas com "burnout" e qualidade de vida, de que não se falava até há alguns anos, mas que agora estão na ordem do dia e são essenciais na equação da qualidade do internato que queremos dar aos nossos internos; cada vez mais o fator qualidade de vida é tido em consideração pelos jovens médicos ao escolherem a especialidade; os responsáveis a vários níveis (Ordem dos Médicos, Sociedades Científicas e os hospitais, públicos ou privados) devem ter isso em consideração se pretendem manter a respetiva especialidade ou instituição "popular" e atrair os melhores internos;

- Aplicação das novas regras do Serviço de Urgência para os médicos internos (circular informativa 9/2017 da ACSS).

Em suma, temas essenciais para a qualidade da formação médica pós-graduada, que é reconhecida como excelente no nosso país, mas que corre riscos sérios de se deteriorar.

Estes problemas não têm solução fácil.

Não vamos conseguir aumentar significativamente as capacidades formativas para internato em Portugal, pelo menos sem pôr em causa a qualidade da formação; nem vamos conseguir aumentar os formadores ou a sua motivação a curto prazo. 
Voltando à nossa realidade CUF, e tendo em consideração todo este panorama, os grupos privados de saúde que apostaram no Internato Médico passaram também a ter responsabilidade na resposta a estes desafios. Que são, também, uma oportunidade única para se afirmarem como formadores de qualidade na área da formação médica pós-graduada e combater alguns preconceitos ainda existentes sobre este assunto, tanto entre os médicos como entre os decisores políticos.

Sei que esta é uma oportunidade que não podemos perder. E sei que a Academia CUF, responsável no nosso grupo por toda a formação, tem a mesma visão. O internato é uma força inesgotável de melhoria assistencial e científica. Que pode mudar para muito melhor o paradigma de funcionamento clínico das instituições de saúde.

Temos, sim, de oferecer qualidade formativa e oportunidades de desenvolvimento profissional de excelência, para atrair os melhores. E temos profissionais, casuística e estrutura para isso. Não tenho quaisquer dúvidas!

É o que já estamos a fazer nos Hospitais CUF Descobertas em Imuno-Alergologia, Ortopedia, Otorrinolaringologia e Pediatria e no Hospital CUF Infante Santo em Otorrinolaringologia, especialidades em que já temos idoneidade formativa.

Numa reflexão sobre os primeiros 5 anos de Internato Médico nos Hospitais CUF realizada este ano, os nossos internos apresentaram os fatores positivos e negativos do seu internato connosco.

Entre vários pontos referidos, o que mais me marcou foi terem sido unânimes em declarar que voltariam a escolher os hospitais CUF para fazer o internato se o tivessem de fazer agora com o que já sabem.

Isto dá-nos alento e entusiasmo para trabalhar mais.

E levar a nossa visão muito mais longe.

Queremos "dar cartas" em muitas outras áreas relativamente à formação médica pós-graduada no universo CUF, e estamos a trabalhar nesse sentido.

Para isso precisamos do envolvimento de todos para nos ajudarem neste ambicioso projeto.

E podem, claro, contar com a Academia CUF e comigo para desenvolver os vossos projetos de Internato Médico nos hospitais CUF.

Vamos a isto!

João Paulo Farias Diretor do Internato Médico CUF 